\title{
Effect of irrigation regimes and nitrogen levels on phenology and grain yield of late sown wheat
}

\author{
Mukesh Kumar*, Raj Kumar Pannu and Bhagat Singh \\ CCS Haryana Agricultural University, Hisar, India
}

\section{Article history}

Received: 16 January 2017

Revised : 15 January 2018

Accepted: 25 February 2018

\section{Citation}

Kumar M, RK Pannu and B Singh. 2018. Effect of irrigation regimes and nitrogen levels on phenology and grain yield of late sown wheat. Wheat and Barley Research 10(1): 1519. doi.org/ 10.25174/2249-4065/ 2018/66913.

\section{"Corresponding author}

Email:mukeshkumarkainwal@gmail. com

(C) Society for Advancement of Wheat and Barley Research

\begin{abstract}
A field experiment was conducted to study the response of irrigation regimes and nitrogen levels on phenology and grain yield of late sown wheat. The experiment consisting of three irrigation regimes viz. one irrigation (at CRI), two irrigations at (CRI and heading) and four irrigations at (CRI, late tillering, heading and milking) in main plots and five nitrogen levels viz. control i.e. 0, 50, 100, 150 and 200 $\mathrm{kg} \mathrm{N} / \mathrm{ha}$ in sub-plots was laid out in strip plot design. Days taken to heading, anthesis and physiological maturity delayed significantly with increased irrigation regimes and nitrogen levels. Similarly, plant height, dry matter accumulation, crop growth rate (CGR) and leaf area index (LAI) increased significantly with increased irrigation regimes from one to two and two to four irrigations and dose of nitrogen. The grain yield increased by 50.6 and $47.5 \%$ over one irrigation and 20.4 and $21.9 \%$ over two irrigations in four irrigations (3832 and $3989 \mathrm{~kg}$ / ha) during 2010-11 and 2011-12, respectively. The growth parameters namely plant height, LAI, dry matter accumulation and CGR showed significant positive relationship with grain yield. Increase in dose of nitrogen increased the grain yield significantly up to $150 \mathrm{~kg}$ N/ha during both the year. However, the grain yield of wheat was statistically at par with 150 and $200 \mathrm{~kg} \mathrm{~N} / \mathrm{ha}$.
\end{abstract}

Keywords: Grain yield, Irrigation regimes, late sown wheat, nitrogen

\section{Introduction}

Wheat (Triticum aestivum L.) is the second most important cereal crop after rice, grown under diverse agro-climatic conditions. During past few years, sowing of wheat often gets delayed till December or early January causing substantial loss in grain yield. This is primarily attributed to non availability of pre-sowing irrigation or owing to late harvest of preceding crop as a compulsion and not a choice of the farmers under, American cotton-wheat, basmati rice-wheat, rice-potato-wheat and sugarcanewheat rotations.

Water and nitrogen are the two most important inputs in high-yield wheat cultivation. Wheat is highly responsive to irrigation application. Water is vital to every stage of wheat plant development from seed germination to plant maturation. Irrigation applied at sensitive stages would be a valuable management practice for improving yield. Decreased growth rate is caused primarily by reduction in radiation use efficiency, when drought was imposed at various growth stages such as tillering, booting, ear head emergence, anthesis and grain development stages. The best performance of crop depends upon availability of water during these stages. Efficient water supply during the early growing season increases the leaf area of the crop; enable it to intercept most of the incoming radiation (Asif et al., 2012). Nitrogen a key element for plant nutrition an essential constituent of protein, which is associated with all the vital processes in plants. It increases LAI by increasing leaf production and expansion rate that 
effect interception of photosynthetically active radiation $(\mathrm{PAR})$ and consequently the final dry matter production (Asif et al., 2012). Nitrogen is one of the major essential nutrients applied to the crop for higher vegetative growth, productivity and quality (Ali et al., 2012 and Iqbal et al., 2012). Kibe et al. (2006) studied nitrogenwater relationships in late cultivation of wheat crop with adequate and limited irrigation regimes. The results revealed that an increase in irrigation water and nitrogen led to increases in LAI, CGR, RGR, NAR and yield.

There was significant positive interaction between irrigation and nitrogen levels with respect to grain yield, water productivity and nitrogen use efficiency of wheat (Pradhan et al., 2013).

\section{Material and methods}

Field experiment was conducted during 2010-11 and 2011-12 at Agronomy Research Farm of CCS Haryana Agricultural University, Hisar (India) with latitude of $29^{\circ} 10^{\prime}$ North and longitude of $75^{\circ} 46^{\prime}$ East at 215.2 meters above mean sea level. The soil of the field was sandy loam, having $0.39 \%$ organic carbon and $\mathrm{pH}$ 7.95. It was low in available $\mathrm{N}(156.1 \mathrm{~kg} / \mathrm{ha})$, medium in available $\mathrm{P}$ $(10.5 \mathrm{~kg} / \mathrm{ha})$ and rich in available $\mathrm{K}(306.4 \mathrm{~kg} / \mathrm{ha})$. The experiment consisting of three irrigation regimes viz. one irrigation at CRI, two irrigations at CRI and heading and four irrigations at CRI, late tillering, heading and milking in main plots and five nitrogen levels viz. control i.e. 0, $50,100,150$ (recommended dose of nitrogen) and $200 \mathrm{~kg}$ $\mathrm{N} / \mathrm{ha}$ in sub-plots was laid out in strip plot design with four replications.

Fertilizer $\mathrm{P}$ and $\mathrm{K}$ applied as basal dose @60 kg each $\mathrm{P}_{2} \mathrm{O}_{5}$ and $\mathrm{K}_{2} \mathrm{O} /$ ha. The nitrogen doses were applied in the form of urea. Half dose of nitrogen was applied as basal dose and remaining half as top dressed after 1st irrigation as per treatments. Wheat cv. WH 1021 was sown with the help of seed drill in rows $18 \mathrm{~cm}$ apart at the seed rate of $125 \mathrm{~kg} / \mathrm{ha}$. Crop was sown on 18th December during both the years. The weeds were removed by hand hoeing and hand pulling. The growth parameters were recorded at 30 days interval till crop maturity. Data on plant height, dry weight, LAI, CGR and grain yield were recorded by using standard procedure. Data were analysed statistically with OPSTAT software.

\section{Results and discussion}

The time taken for phenological development in wheat under different irrigations was recorded at emergence, heading, anthesis and physiological maturity (Table 1).
Application of four irrigations resulted in significant delay in heading, anthesis and physiological maturity by 3,3 and 3.4 days and 4.4, 4.6 and 6 Days in 2010-11 and 2.5, 3,3 days and 4, 5, 5.6 days in 2011-12, respectively over crop irrigated twice and crop given one irrigation. The significant delay in development of different phenophases in four irrigations may be due to more availability of irrigation water and continuous availability of moisture to the crop because of frequent irrigation. This high availability of moisture increased the plant growth. The longer crop duration and longer reproductive phase of crop growth under higher level of irrigation has been also reported by Dhaka et al. (2006) and Ngwako and Mashiqa (2013).

Increase in crop duration by three to four days in well fertilized crop was significant over control. Increase in days to heading, anthesis and maturity may be attributed to the increased vegetative growth and increased light use efficiency with the increase of $\mathrm{N}$ doses. Higher level of nitrogen enhances cell division and enlargement leading to the new tissue development in the younger leaves, which slowed down the development of phenophases and finally slowed down the process of senescence, hence delayed the maturity (Rehman et al., 2010).

LAI increased up to $90 \mathrm{DAS}$ and declined thereafter, during both the years (Table 2). The maximum LAI was recorded with maximum number of irrigations i.e. four, which was significantly higher than two and one irrigation at 90 DAS. Efficient water supply during the growing season increased the leaf area of the crop; enabling it to intercept most of the incoming radiation. These results were in confirmation with Asif et al. (2012) and Kumar et al. (2012). Similarly, application of nitrogen doses also influenced the LAI significantly at all the stages of crop growth during two years of study. The maximum LAI was observed with $200 \mathrm{~kg} \mathrm{~N} /$ ha followed by $150,100,50 \mathrm{~kg}$ $\mathrm{N} / \mathrm{ha}$ and minimum LAI was found in control i.e. $0 \mathrm{~kg}$ $\mathrm{N} / \mathrm{ha}$, which was significantly lower than other doses of nitrogen at all the stages of crop growth during both the years. However, in 2010-11, LAI found in $200 \mathrm{~kg} \mathrm{~N} /$ ha was significantly higher than $100 \mathrm{~kg} \mathrm{~N} / \mathrm{ha}$, but in 2011-12 it was statistically at par with $100 \mathrm{~kg} \mathrm{~N} / \mathrm{ha}$. Whereas, LAI at 150 $\mathrm{kg} \mathrm{N} /$ ha statistically at par with 100 and $200 \mathrm{~kg} \mathrm{~N} / \mathrm{ha}$ at all the stages of crop growth during 2010-11 and 2011-12. The increase in leaf area index with higher $\mathrm{N}$ levels might be due to more leaf area on account of more accumulation of assimilates. Asif et al. (2012) reported enhanced LAI by application of higher levels of $\mathrm{N}$ fertilizer. 
The plant height and dry matter accumulation increased significantly with increase in number of irrigations during both the years (Table 4), because of more water availability to the crop plants. The higher amount of available water kept the higher turgor potential, which lead to higher rate of photosynthesis due to more opening of stomata for longer period of time. Similar findings were also recorded by Pannu and Sharma (2004), Kumar et al. (2012) and Shirazi et al. (2014). The increase in nitrogen dose increased the plant height and dry matter accumulation up to $100 \mathrm{~kg} \mathrm{~N} / \mathrm{ha}$. At highest dose of $200 \mathrm{~kg} \mathrm{~N} / \mathrm{ha}$, the increase in plant height and dry weight was significantly higher than $100 \mathrm{~kg} \mathrm{~N} /$ ha. However, the differences at 150 $\mathrm{kg} \mathrm{N} /$ ha was statistically at par with 100 and $200 \mathrm{~kg} \mathrm{~N} /$ ha. Significantly lower plant height and dry weight were observed in control than other doses of nitrogen might be because of under nourishment of the plant, because of low availability of nutrients. Similar results were confirmed by Rehman et al. (2010), Ali et al. (2011), Shahzad et al. (2013) and Shirazi et al. (2014).

Crop growth rate (CGR) was lowest between 0-30 days increased till 90 days and attained maximum value between 60-90 days and then declined consistently till crop maturity (Table 3). The CGR increased with increase in number of irrigations significantly during both the years at later stages of crop growth i.e. 90-120 DAS and 120 DAS-maturity. The difference in CGR at 0-30 DAS were non significant and between 60-90 DAS CGR having one irrigation is significantly lower than higher levels of irrigation. However, between 60-90 days interval CGR of two irrigations and four irrigations were statistically at par.
Nitrogen application increases the CGR of late sown wheat. With advancement of crop growth between 30-60 DAS CGR increases significantly up to $100 \mathrm{~kg} \mathrm{~N} / \mathrm{ha}$. CGR at $0 \mathrm{Kg} \mathrm{N} /$ ha was significantly lower than all other doses of nitrogen at all the growth stages. The CGR at 60-90 DAS increased with each level of increase in nitrogen dose. Although, the crop responded significantly up to $50 \mathrm{~kg} \mathrm{~N} /$ ha during 2010-11, but during 2011-12 the CGR recorded at $200 \mathrm{~kg} \mathrm{~N} /$ ha was significantly higher than 50 $\mathrm{kg} \mathrm{N} / \mathrm{ha}$. However, it was at par in 100,150 and $200 \mathrm{~kg}$ $\mathrm{N} /$ ha. Asif et al. (2012) also found that CGR increases with increasing levels of irrigation and nitrogen. The increase in irrigation number from one to two, two to four and one to four irrigations increased the grain yield of wheat by about 25.1, 20.4 and 50.6 \% during 2010-11 and 21.0, 21.9 and $47.5 \%$ during 2011-12, respectively (Table 4). The maximum grain yield of 3832 and $3989 \mathrm{~kg} / \mathrm{ha}$ was obtained with four irrigations which was significantly higher as compared to two irrigations and minimum in one irrigation, which was significantly lower than two and four irrigations during first and second year, respectively. The higher irrigation regimes fulfilled the timely crop water requirement and continuous availability of moisture to the crop because of frequent irrigation, which resulted into better growth ultimately grain yield. Similar results were also observed by Wang et al. (2012), Pradhan et al. (2013) and Shirazi et al. (2014).

The wheat grain yield increased significantly with increased dose of nitrogen. The minimum grain yield was found in control (1932 and $2026 \mathrm{~kg} / \mathrm{ha}$ ) and the increase in yield was significant up to $150 \mathrm{~kg} \mathrm{~N} /$ ha during both the years of study.

Table 1. Effect of irrigation regimes and nitrogen levels on phenophases (days) of late sown wheat

\begin{tabular}{|c|c|c|c|c|c|c|c|c|}
\hline \multirow[t]{2}{*}{ Treatments } & \multicolumn{2}{|c|}{ Emergence } & \multicolumn{2}{|c|}{ Heading } & \multicolumn{2}{|c|}{ Anthesis } & \multicolumn{2}{|c|}{ Maturity } \\
\hline & $2010-11$ & 2011-12 & 2010-11 & 2011-12 & 2010-11 & 2011-12 & 2010-11 & 2011-12 \\
\hline \multicolumn{9}{|c|}{ Irrigation levels } \\
\hline $\begin{array}{l}\text { One } \\
\text { Two } \\
\text { Four } \\
\text { CD at } 5 \%\end{array}$ & $\begin{array}{l}11.4 \\
11.4 \\
11.1 \\
\text { NS }\end{array}$ & $\begin{array}{l}11.2 \\
11.5 \\
11.4 \\
\text { NS }\end{array}$ & $\begin{array}{c}82.8 \\
84.1 \\
87.2 \\
0.8\end{array}$ & $\begin{array}{c}83.9 \\
85.4 \\
87.9 \\
1.7\end{array}$ & $\begin{array}{c}88.1 \\
89.5 \\
92.7 \\
1.3\end{array}$ & $\begin{array}{c}89.2 \\
91.3 \\
94.3 \\
1.7\end{array}$ & $\begin{array}{c}121.2 \\
123.8 \\
127.2 \\
1.8\end{array}$ & $\begin{array}{c}122.7 \\
125.2 \\
128.3 \\
1.6\end{array}$ \\
\hline \multicolumn{9}{|c|}{ Nitrogen (kg/ha) } \\
\hline $\begin{array}{l}0 \\
50 \\
100 \\
150 \\
200 \\
\text { CD at } 5 \%\end{array}$ & $\begin{array}{l}11.7 \\
11.6 \\
11.3 \\
11.0 \\
10.8 \\
\text { NS }\end{array}$ & $\begin{array}{l}11.8 \\
11.6 \\
11.4 \\
11.0 \\
10.9 \\
\text { NS }\end{array}$ & $\begin{array}{c}83.5 \\
84.1 \\
84.7 \\
85.3 \\
85.8 \\
1.2\end{array}$ & $\begin{array}{c}84.5 \\
85.2 \\
85.8 \\
86.5 \\
86.8 \\
1.3\end{array}$ & $\begin{array}{c}88.4 \\
89.5 \\
90.2 \\
90.9 \\
91.5 \\
1.2\end{array}$ & $\begin{array}{c}89.9 \\
91.0 \\
91.6 \\
92.6 \\
93.0 \\
1.4\end{array}$ & $\begin{array}{c}122.3 \\
123.6 \\
124.1 \\
125.0 \\
125.4 \\
1.5\end{array}$ & $\begin{array}{c}123.5 \\
124.8 \\
125.3 \\
126.6 \\
126.9 \\
1.4\end{array}$ \\
\hline
\end{tabular}


Table 2. Effect of irrigation regimes and nitrogen levels on leaf area index (LAI) of late sown wheat

\begin{tabular}{|c|c|c|c|c|c|c|c|c|}
\hline \multirow[t]{3}{*}{ Treatments } & \multicolumn{8}{|c|}{ Leaf Area Index (LAI) } \\
\hline & \multicolumn{2}{|c|}{$30 \mathrm{DAS}$} & \multicolumn{2}{|c|}{$60 \mathrm{DAS}$} & \multicolumn{2}{|c|}{$90 \mathrm{DAS}$} & \multicolumn{2}{|c|}{$120 \mathrm{DAS}$} \\
\hline & 2010-11 & 2011-12 & 2010-11 & 2011-12 & 2010-11 & 2011-12 & 2010-11 & 2011-12 \\
\hline \multicolumn{9}{|c|}{ Irrigation levels } \\
\hline $\begin{array}{l}\text { One } \\
\text { Two } \\
\text { Four } \\
\text { CD at 5\% }\end{array}$ & $\begin{array}{c}0.21 \\
0.24 \\
0.22 \\
\mathrm{NS} \\
\end{array}$ & $\begin{array}{c}0.24 \\
0.25 \\
0.23 \\
\mathrm{NS} \\
\end{array}$ & $\begin{array}{l}2.21 \\
2.17 \\
2.63 \\
0.23 \\
\end{array}$ & $\begin{array}{l}2.25 \\
2.32 \\
2.63 \\
0.15 \\
\end{array}$ & $\begin{array}{l}2.69 \\
3.39 \\
3.81 \\
0.23 \\
\end{array}$ & $\begin{array}{l}2.83 \\
3.45 \\
3.82 \\
0.16 \\
\end{array}$ & $\begin{array}{l}0.55 \\
0.69 \\
0.79 \\
0.15 \\
\end{array}$ & $\begin{array}{l}0.60 \\
0.70 \\
0.82 \\
0.16 \\
\end{array}$ \\
\hline \multicolumn{9}{|c|}{ Nitrogen $(\mathrm{kg} / \mathrm{ha})$} \\
\hline $\begin{array}{l}0 \\
50 \\
100 \\
150 \\
200 \\
\text { CD at } 5 \%\end{array}$ & $\begin{array}{l}0.15 \\
0.20 \\
0.23 \\
0.25 \\
0.27 \\
0.05\end{array}$ & $\begin{array}{l}0.17 \\
0.23 \\
0.25 \\
0.27 \\
0.28 \\
0.03\end{array}$ & $\begin{array}{l}2.04 \\
2.23 \\
2.39 \\
2.49 \\
2.54 \\
0.28\end{array}$ & $\begin{array}{l}2.07 \\
2.37 \\
2.52 \\
2.58 \\
2.61 \\
0.20\end{array}$ & $\begin{array}{l}2.60 \\
3.17 \\
3.45 \\
3.60 \\
3.68 \\
0.20\end{array}$ & $\begin{array}{l}2.66 \\
3.23 \\
3.52 \\
3.67 \\
3.74 \\
0.23\end{array}$ & $\begin{array}{l}0.48 \\
0.61 \\
0.71 \\
0.78 \\
0.82 \\
0.12\end{array}$ & $\begin{array}{l}0.52 \\
0.65 \\
0.73 \\
0.80 \\
0.84 \\
0.09\end{array}$ \\
\hline
\end{tabular}

Table 3. Effect of irrigation regimes and nitrogen levels on crop growth rate $\left(\mathrm{CGR}, \mathrm{g} / \mathrm{m}^{2} /\right.$ day) at different growth intervals of late sown wheat

\begin{tabular}{|c|c|c|c|c|c|c|c|c|c|c|}
\hline \multirow[t]{3}{*}{ Treatments } & \multicolumn{8}{|c|}{ Days after sowing } & & \\
\hline & \multicolumn{2}{|c|}{$0-30$} & \multicolumn{2}{|c|}{$30-60$} & \multicolumn{2}{|c|}{$60-90$} & \multicolumn{2}{|c|}{$120 \mathrm{DAS}$} & \multicolumn{2}{|c|}{ 120- Maturity } \\
\hline & 2010-11 & 2011-12 & 2010-11 & 2011-12 & 2010-11 & 2011-12 & 2010-11 & 2011-12 & 2010-11 & 2011-12 \\
\hline \multicolumn{11}{|c|}{ Irrigation levels } \\
\hline $\begin{array}{l}\text { One } \\
\text { Two } \\
\text { Four } \\
\text { CD at } 5 \%\end{array}$ & $\begin{array}{c}0.40 \\
0.42 \\
0.41 \\
\text { NS } \\
\end{array}$ & $\begin{array}{c}0.41 \\
0.40 \\
0.40 \\
\text { NS }\end{array}$ & $\begin{array}{l}7.36 \\
7.38 \\
9.43 \\
0.39 \\
\end{array}$ & $\begin{array}{l}7.68 \\
7.62 \\
9.75 \\
0.32 \\
\end{array}$ & $\begin{array}{c}19.85 \\
21.83 \\
21.98 \\
0.96 \\
\end{array}$ & $\begin{array}{c}20.21 \\
21.89 \\
21.99 \\
1.01 \\
\end{array}$ & $\begin{array}{l}3.90 \\
4.62 \\
8.16 \\
1.22 \\
\end{array}$ & $\begin{array}{l}3.44 \\
4.69 \\
8.13 \\
0.89 \\
\end{array}$ & $\begin{array}{l}0.73 \\
2.97 \\
5.77 \\
1.74 \\
\end{array}$ & $\begin{array}{l}1.76 \\
3.88 \\
6.44 \\
1.81 \\
\end{array}$ \\
\hline \multicolumn{11}{|c|}{ Nitrogen (kg/ha) } \\
\hline $\begin{array}{l}0 \\
50 \\
100 \\
150 \\
200 \\
\mathrm{CD} \text { at } 5 \%\end{array}$ & $\begin{array}{l}0.37 \\
0.40 \\
0.41 \\
0.42 \\
0.42 \\
0.02\end{array}$ & $\begin{array}{l}0.38 \\
0.40 \\
0.41 \\
0.41 \\
0.42 \\
0.03\end{array}$ & $\begin{array}{l}6.75 \\
7.69 \\
8.29 \\
8.66 \\
8.87 \\
0.65\end{array}$ & $\begin{array}{l}7.00 \\
7.98 \\
8.62 \\
9.00 \\
9.17 \\
0.69\end{array}$ & $\begin{array}{c}19.86 \\
20.97 \\
21.56 \\
21.71 \\
22.01 \\
1.60\end{array}$ & $\begin{array}{c}19.96 \\
21.07 \\
21.69 \\
21.93 \\
22.16 \\
0.54\end{array}$ & $\begin{array}{l}4.89 \\
5.49 \\
5.68 \\
5.86 \\
5.89 \\
1.08\end{array}$ & $\begin{array}{l}4.96 \\
5.39 \\
5.48 \\
5.63 \\
5.66 \\
1.38\end{array}$ & $\begin{array}{l}1.26 \\
2.51 \\
3.62 \\
3.82 \\
4.57 \\
1.48\end{array}$ & $\begin{array}{l}2.43 \\
3.49 \\
4.17 \\
4.88 \\
5.15 \\
1.30\end{array}$ \\
\hline
\end{tabular}

Table 4. Effect of irrigation regimes and nitrogen levels on growth and grain yield of late sown wheat

\begin{tabular}{|c|c|c|c|c|c|c|c|}
\hline \multirow[t]{2}{*}{ Treatments } & \multicolumn{2}{|c|}{ Plant height $(\mathrm{cm})$} & \multicolumn{2}{|c|}{ Dry weight (g/mrl) } & \multicolumn{3}{|c|}{ Grain yield (kg/ ha) } \\
\hline & 2010-11 & 2011-12 & 2010-11 & 2011-12 & 2010-11 & 2011-12 & Pooled \\
\hline \multicolumn{8}{|c|}{ Irrigation levels } \\
\hline $\begin{array}{l}\text { One } \\
\text { Two } \\
\text { Four } \\
\text { CD at } 5 \%\end{array}$ & $\begin{array}{c}80.8 \\
90.9 \\
98.8 \\
1.8\end{array}$ & $\begin{array}{c}82.5 \\
89.6 \\
100.5 \\
3.4 \\
\end{array}$ & $\begin{array}{c}171.4 \\
189.3 \\
224.4 \\
3.1 \\
\end{array}$ & $\begin{array}{c}174.1 \\
192.6 \\
226.9 \\
7.5\end{array}$ & $\begin{array}{c}2544 \\
3183 \\
3832 \\
190\end{array}$ & $\begin{array}{c}2704 \\
3272 \\
3989 \\
183\end{array}$ & $\begin{array}{c}2624 \\
3228 \\
3911 \\
136 \\
\end{array}$ \\
\hline \multicolumn{8}{|c|}{ Nitrogen (kg/ha) } \\
\hline $\begin{array}{l}0 \\
50 \\
100 \\
150 \\
200 \\
\mathrm{CD} \text { at } 5 \%\end{array}$ & $\begin{array}{l}11.7 \\
11.6 \\
11.3 \\
11.0 \\
10.8 \\
\text { NS }\end{array}$ & $\begin{array}{l}11.8 \\
11.6 \\
11.4 \\
11.0 \\
10.9 \\
\text { NS }\end{array}$ & $\begin{array}{c}83.5 \\
84.1 \\
84.7 \\
85.3 \\
85.8 \\
1.2\end{array}$ & $\begin{array}{c}84.5 \\
85.2 \\
85.8 \\
86.5 \\
86.8 \\
1.3\end{array}$ & $\begin{array}{c}88.4 \\
89.5 \\
90.2 \\
90.9 \\
91.5 \\
1.2\end{array}$ & $\begin{array}{c}89.9 \\
91.0 \\
91.6 \\
92.6 \\
93.0 \\
1.4\end{array}$ & $\begin{array}{c}1979 \\
3005 \\
3549 \\
3815 \\
3922 \\
120\end{array}$ \\
\hline
\end{tabular}


However, the yield of $150 \mathrm{~kg} \mathrm{~N} /$ ha was statistically at par with $200 \mathrm{~kg} \mathrm{~N} /$ ha during both years. The improvement in wheat yield and its components with increasing $\mathrm{N}$ rates were also obtained by Shirazi et al. 2014.

\section{Conclusion}

From the results of two year study during 2010-11 and 2011-12, it can be concluded that increasing irrigation regimes and $\mathrm{N}$ doses delay the days to heading, anthesis and physiological maturity. Grain yield improved significantly with increased irrigation regimes and nitrogen doses. Yield increased significantly up to $150 \mathrm{~kg} \mathrm{~N} / \mathrm{ha}$. Four irrigations at CRI, late tillering, heading and milking with $150 \mathrm{~kg} \mathrm{~N} /$ ha is the best option for getting higher wheat yield.

\section{References}

1. Ali A, A Ahmad, WH Syed, T Khaliq, M Asif, M Aziz and M Mubeen. 2011. Effect of nitrogen on growth and yield component of wheat. Science International 23:331-332.

2. Ali A, T Khaliq, A Ahmad, S Ahmad, A Ullah and R Fahd. 2012. How wheat response to nitrogen in the field. Crop and Environment 3(1-2):71-76.

3. Asif M, M Maqsood, A Ali, SW Hassan, A Hussain, S Ahmad and MA Javed. 2012. Growth, yield components and harvest index of wheat (Triticum aestivum $\mathrm{L}$.) affected by different irrigation regimes and nitrogen management strategy. Science International 24(2):215-218.

4. Dhaka AK, AS Bangarwa, RK Pannu, RK Malik and R Garg. 2006. Phenological development, yield and yield attributes of different wheat genotypes as influenced by sowing time and irrigation. Agricultural Science Digest 26(3): 174-177.

5. Iqbal J, K Hayat, S Hussain, A Ali, M Ahmad, A Haji and B Ahmad. 2012. Effect of seeding rates and nitrogen levels on yield and yield components of wheat (Triticum aestivum L.). Pakistan Journal Nutrition 11(7):531-536.

6. Kibe AM, S Singh and N Kalra. 2006. Water-nitrogen relationships for wheat growth and productivity in late sown conditions. Agricultural Water Management 84: 221-228.
7. Kumar P, RK Pannu and SK Khokar. 2012. Effect of organic sources of nutrition and irrigation levels on growth and yield of wheat (T. aestivum L.). International Journal of life Science, Botany and Pharma Research 1: $178-186$.

8. Ngwako S and PK Mashiqa. 2013. The effect of irrigation on the growth and yield of winter wheat (Triticum aestivum L.) cultivars. International Journal of Agricultural and Crop Sciences 5(9):976-982.

9. Pannu RK and KD Sharma. 2004. Selection of wheat genotypes for limited irrigation under shallow water table condition. Haryana Journal of Agronomy 20(1): 59-61.

10. Pradhan S, UK Chopra, KK Bandhopadyay, R Singh, AK Jain and I Chand. 2013. Effect of water and nitrogen management on water productivity and nitrogen use efficiency of wheat in a semi-arid environment. International Journal of Agricultural and Food Sciences Technology 4(7):727-732.

11. Rehman S, S Khalil, F Muhammad, A Rehman, A Khan, A Rehman, M Zubair and I Khalil. 2010. Phenology, leaf area index and grain yield of rainfed wheat influenced by organic and inorganic fertilizers. Pakistan Journal of Botany 42(5): 3671-3685.

12. Shahzad MA, MD Maqsood, S Iqbal, MD Saleem, MU Hasan and W Ahmad. 2013. Impact of nutrition and moisture deficits on growth, yield and radiation use efficiency of wheat (Triticum aestivum L.). African Journal of Biotechnology 11(75):13980-13987.

13. Shirazi SM, Z Yusop, NH Zardari and Z Ismail. 2014. Effect of irrigation regimes and nitrogen levels on the growth and yield of wheat. Advances in Agriculture 123:1-6.

14. Wang QI, LI Fengrui, E Zhang, L Guan and M Vance. 2012. The effects of irrigation and nitrogen application rates on yield of spring wheat (longfu-920), and water use efficiency and nitrate nitrogen accumulation in soil. Australian Journal of Crop Sciences 6(4):662-672. 